\title{
12 \\ Skeletal markers of health and disease in the Northern Moluccas
}

\author{
Bronwyn Wyatt and Justyna J. Miszkiewicz
}

This chapter seeks to understand how skeletal markers of systemic stress, especially those indicating childhood exposure to external or internal non-specific physiological disruptions, may have influenced longer-term growth and mortality in late prehistoric Maluku Utara. It explores the presence, severity, and distribution of pathology within the studied samples, focusing on systemic stress indicators. It discusses whether we can infer longer-term health outcomes in these populations.

The environments in which contemporary humans live are a testament to the adaptability and resilience of the ancient humans who first reached them. Many barriers of land, sea, and environmental unpredictability were overcome, shaping the responses of ancient human physiology. These responses are likely to be reflected in the surviving physical evidence representing ancient humans - their skeletal remains (Larsen 2015). By examining such remains, insights into the past biocultural experiences of individuals, and the populations from which they originated, can be gained. These insights come from skeletal markers of health and disease that allow us to infer likely diets (including the sufficiency of diet), subsistence practices, experiences of infectious diseases, and adaptations to new environments with novel challenges (Roberts and Manchester 2007).

The ancient seafaring populations of Island Southeast Asia, Melanesia, and the Pacific Islands represent groups of humans who successfully colonised new islands. Their skeletal remains are thus an important source of data for bioarchaeology and paleopathology. The Northern Moluccas islands in Indonesia (Propinsi Maluku Utara) have long been an important meeting ground between Austronesian- and Papuan-speaking populations, with exchange and modification of cultural and technological practices observed through the archaeological, linguistic, and genetic records (Bellwood 1998, 2017; Bellwood et al. 2006; Bulbeck 2008; Spriggs 1998).

Following on from Chapter 11, here the analysis of human skeletal remains recovered from the Northern Moluccan excavations is extended, by discussing skeletal markers of physiological stress in the context of age-at-death and stature. For information regarding the ancestry and antiquity of the sample, please see Chapter 11. 


\section{Materials and methods}

The study sample includes human skeletal remains from five sites in the three islands of Kayoa, Morotai, and Gebe (see Table 12.1). The cultural contexts of these burials can be classified as Late Neolithic (Golo, Tanjung Pinang, and Daeo 1 and 2) and Early Metal Phase (Uattamdi). They belong to a period when pottery making was already present, with glass beads and metal artefacts (copper, iron) appearing around 2000 years ago in Uattamdi. Subsistence resources included pigs and dogs (chickens are uncertain), with presumably a range of tropical tuber, starch-bearing, and fruit/nut species such as yam, taro, banana, sago, canarium, coconut, and breadfruit. No actual plant remains were recovered during the excavations, so the plant food aspect of the diet remains rather hypothetical, but there is no reason to suspect from the regional archaeological record that cereals such as rice or millet were present in this region.

Table 12.1 Basic biological profiles for the sample.

\begin{tabular}{|c|c|c|c|}
\hline Individual & Age-at-death & Sex & Location \\
\hline Tanjung Pinang 1 & Adolescent to young adult $\neq \S$ & Male & Morotai \\
\hline Tanjung Pinang 2 & Adult†‡ $\oint$ & Male & Morotai \\
\hline Tanjung Pinang 3 & Young adult & Male & Morotai \\
\hline Tanjung Pinang 4 & Young adulttł & Male & Morotai \\
\hline Tanjung Pinang 5 & Subadult†§ & Male & Morotai \\
\hline Tanjung Pinang 6 & Adolescent to young adult $\S$ & Male & Morotai \\
\hline Tanjung Pinang 9 & Subadult" & Indeterminate ${ }^{\wedge}$ & Morotai \\
\hline Tanjung Pinang 10 & Adult $^{*}$ & Male & Morotai \\
\hline Tanjung Pinang Unknown 1 Adult & Adult\# & Indeterminate ${ }^{\wedge}$ & Morotai \\
\hline Tanjung Pinang Unknown 2 child & Child" & Indeterminate ${ }^{\wedge}$ & Morotai \\
\hline Tanjung Pinang Unknown 3 subadult & Subadult\#" & Indeterminate ${ }^{\wedge}$ & Morotai \\
\hline Tanjung Pinang Unknown 4 subadult & Adolescent to young adult\#" & Indeterminate^ & Morotai \\
\hline Tanjung Pinang Unknown 5 Adult & Adult\#" $^{*}$ & Indeterminate ${ }^{\wedge}$ & Morotai \\
\hline Tanjung Tulang Adult 1 & Adult" & Male & Morotai \\
\hline Tanjung Tulang Juvenile & Subadult" & Indeterminate ${ }^{\wedge}$ & Morotai \\
\hline Tanjung Tulang Adult 2 & Adult" & Female & Morotai \\
\hline Tanjung Tulang Adult 3 & Adult" & Indeterminate ${ }^{\wedge}$ & Morotai \\
\hline Daeo 1 Adult & Middle-aged adult $\S$ & Male & Morotai \\
\hline Daeo 1 Juvenile & Subadult\# & Indeterminate^ & Morotai \\
\hline Daeo 2-1 Juvenile & Subadult\#" $^{*}$ & Indeterminate ${ }^{\wedge}$ & Morotai \\
\hline Daеo 2-2 & Adult\#" $^{*}$ & Indeterminate ${ }^{\wedge}$ & Morotai \\
\hline Daeo 2-3 & Adult" & Indeterminate ${ }^{\wedge}$ & Morotai \\
\hline Daeo 2-4 & Adult" & Indeterminate ${ }^{\wedge}$ & Morotai \\
\hline Daеo 2-5 & Adult" & Indeterminate ${ }^{\wedge}$ & Morotai \\
\hline Daeo 2-6 & Adolescent to young adult: & Indeterminate^ & Morotai \\
\hline Uattamdi 1 & Middle-aged adult§ & Male & Kayoa \\
\hline Uattamdi 2 & Subadult" & Indeterminate ${ }^{\wedge}$ & Kayoa \\
\hline Uattamdi 3 & Adult\# & Male & Kayoa \\
\hline Uattamdi 4 & Adolescent to young adult & Indeterminate^ & Кауод \\
\hline Uattamdi 5 & Child & Indeterminate^ & Кауоа \\
\hline Uattamdi 6 & Adolescent to young adult: & Indeterminate ${ }^{\wedge}$ & Kayoa \\
\hline Uattamdi 7 & Adult" & Indeterminate ${ }^{\wedge}$ & Kayoa \\
\hline Uattamdi 8 & Child": & Indeterminate ${ }^{\wedge}$ & Kayoa \\
\hline Uattamdi 9 & Adult" & Female & Kaуоа \\
\hline Uattamdi 10 & Adult" & Indeterminate & Kayoa \\
\hline Golo individual associated with cranium & Middle-aged or older adultt§ & Male & Gebe \\
\hline
\end{tabular}


† Dental eruption (Buikstra and Ubelaker 1994)

§ Suture closure (Buikstra and Ubelaker 1994)

$\ddagger$ Dental attrition (Lovejoy 1985)

\# Vertebral changes (Albert 1998)

"Stature or size of remains (Merchant and Ubelaker 1977; Primeau et al. 2012)

^ Remains too fragmentary for reliable estimates.

Source: Bronwyn Wyatt and Justyna Miszkiewicz.

There are remains of 36 individuals in the studied sample. Whilst most display suitable preservation for biological profile reconstruction, the largely fragmentary and incomplete nature of the sample is likely due to it being predominantly comprised of secondary cranial burials, especially from the Tanjung Pinang site on Morotai, with substantially fewer post-cranial elements recovered. Due to the uneven distribution of age groups and sexes in the sample, no inferential statistical examination is attempted, with all assessment being based on descriptive data.

\section{Age-at-death and biological sex estimation}

Following standards for the study of human skeletal remains (Buikstra and Ubelaker 1994), age-at-death was estimated using multiple methods which focus on different skeletal characteristics. The age-at-death estimates were categorised as 'infant or young child' ( 0 to 1 years old), 'older child' (2 to 11 years old), 'adolescent' (12 to 19 years old), 'young adult' (20 to 34 years old), 'middle-aged adult' (35 to 49 years old), and 'older adult' (50+ years old). Due to the fragmentary and largely incomplete record of the remains, multiple age-at-death estimation methods were applied in order to increase the accuracy of estimates for the available material. These included the assessment of cranial suture closure, including palatal sutures, and dental eruption patterns during human development (Buikstra and Ubelaker 1994); dental attrition by life stage as developed by Lovejoy (1985); estimation of age-at-death based on long bone diaphysis length as developed by Merchant and Ubelaker (1977); and the examination of epiphyseal union in the long bones and vertebral body surface changes using standards and criteria described by Buikstra and Ubelaker (1994).

Biological sex was estimated using standards also set out by Buikstra and Ubelaker (1994), with a further five specimens undergoing direct assessment by ancient DNA analysis. Less than half $(n=13)$ of the sample was preserved well enough for reliable sex estimation using macroscopic examination of sex-specific characteristics of the cranium and/or pelvic remains.

\section{Stature estimation}

The estimation of stature in the recovered individuals necessitated use of multiple techniques owing to the fragmentary and incomplete state of the sample. Due to this limitation, the estimates of stature merely provide a starting point for placing these individuals into a broader context of Island Southeast Asian health and physiological attributes. Where possible, multiple methods were used to derive a likely range of stature. The assessment of stature estimates was conducted using regression equations where the maximum length of tibia and femur were available (Genoves 1967), and in some cases following the method of Trotter and Gleser (1958) for the maximum length of the humerus. Given that several of the long bones were incomplete, the method of Steele and McKern (1969) for deriving maximum lengths from bone segments was used. Metatarsal and metacarpal lengths and their relationships to stature, as described by 
Meadows and Jantz (1992) and Byers et al. (1989), were also used, either as supplementary measures, or as sole measures where long bones were not available. Given the difficulties in estimating sex from co-mingled remains without cranial or pelvic bones, the stature estimation regression equations used are based on combined male and female standards. This necessitated creation of a total population average for the slope and intercept of Meadows and Jantz's (1992) methodology, thus increasing the margin of error surrounding true stature. However, where possible, this was offset by the assessment of multiple sites using different methodologies, in order to provide a likely range within which the most accurate stature might have lain.

\section{Assessment of abnormal skeletal lesions to infer disease}

The majority of the individuals in the sample were represented by their cranial vaults. These were examined macroscopically for porous changes indicative of porotic hyperostosis $(\mathrm{PH})$, by locating the affected bone and describing the spread of the lesion (Rivera and Mirazón Lahr 2017). Dental defects characteristic of linear enamel hypoplasia (LEH) (Miszkiewicz 2015) were recorded on a presence/absence and severity basis. Both lesions can be linked to malnutrition and other non-specific forms of physiological health disruption in ancient humans (Miszkiewcz 2015; Rivera and Mirazón Lahr 2017). Exact frequencies and/or estimated chronology of LEH were not assessed given the fragmentary condition of the sample. Where necessary, cranial sites with potential PH and LEH lesions were also investigated with the aid of a hand magnifying glass.

Porotic hyperostosis was described using staging outlined by Schultz (1993), in which the severity and distribution of abnormal porosity to the cranial vault can range from localised to widespread. Enamel depressions indicating LEH were scored where the enamel depression was evident across the labial and buccal surfaces of the anterior and posterior teeth (Miszkiewicz 2015). Individuals were classified as affected by LEH when defects were observed on any teeth, as opposed to per tooth assessments (e.g. Oxenham 2008). This was necessary due to the incomplete nature of the available dental arcades (Goodman and Rose 1990). The LEH defects were scored by examining the occurrence of enamel growth arrests inferred from 'striping' of the labial and buccal surfaces of teeth. This was categorised as absent, single line (present), or multiple lines (present), including an approximate assessment of depth of the depressions (categorised into superficial or prominent). These should facilitate simple insights into the non-specific stress of LEH presence in the sample (Goodman and Rose 1990).

\section{Results}

The bulk of the sample comprised adolescent and young adult individuals $(\mathrm{n}=28)$. Represented are infants or young children $(n=2)$, an older child $(n=1)$, adolescents $(n=13)$, young adults $(n=15)$, middle-aged adults $(n=4)$, and a single elderly adult $(n=1)$. This results in a maximum of 36 individuals, including an estimated 14 males and two females, with the remainder classified as indeterminate (Table 12.1). Estimations of sex ratios and sex-specific differences in health and disease are not attempted. 


\section{Skeletal indicators of stress}

Nine individuals (of 13 available for dental study) demonstrated some degree of macroscopically visible LEH. Six of these showed only mild depressions, localised to the buccal surfaces of teeth, and in most cases only a single affected tooth. The three individuals with more severe LEH demonstrated multiple affected teeth.

Of the 18 available cranial samples, 13 (or 72 per cent of the total crania) demonstrated lesions consistent with PH. Eight (62 per cent) showed severe or widespread lesions. One individual (Uattamdi 1) may have suffered a separate condition, given the severity of the presentation of $\mathrm{PH}$. In each of the 13 individuals who demonstrate skeletal markers of $\mathrm{PH}$, the cranial bones affected also demonstrate substantial thickening (Fig. 12.1, from Tanjung Pinang). The available skeletal material suggests that most individuals were affected by $\mathrm{PH}$ bilaterally, with the frontal

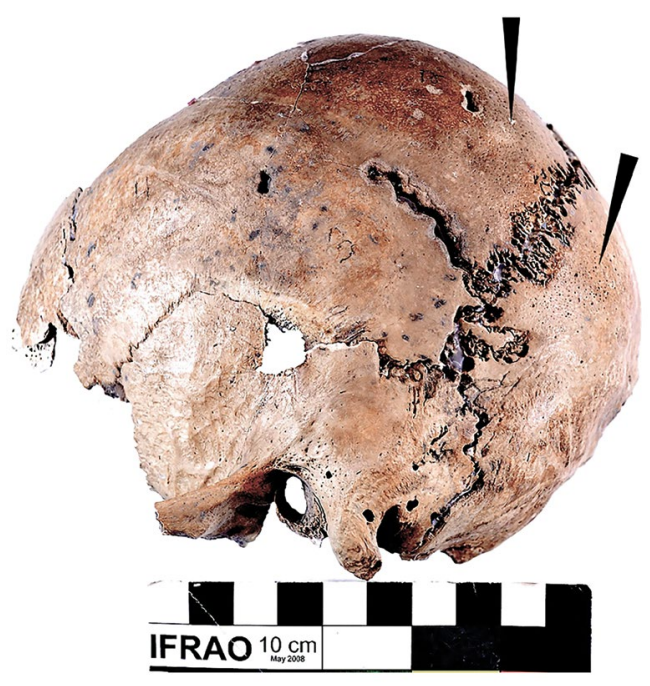

Figure 12.1 Mild porous lesions indicative of porotic hyperostosis to posterior parietal and superior occipital of Tanjung Pinang 6.

Source: Bronwyn Wyatt and Justyna Miszkiewicz. and parietal cranial bones being the most commonly affected sites.

To test whether potential differences in the resources available on Morotai, Gebe, and Kayoa might have had an effect on the skeletal health of these ancient people, the number of individuals with LEH and PH were evaluated and compared between the three islands. Kayoa and Gebe each have only a single individual with associated dental remains. No LEH was observed in the Kayoa (Uattamdi) individual, whilst the Gebe (Golo) individual demonstrated severe LEH. Eight individuals on Morotai were afflicted with LEH. The sole Gebe individual in the sample did not demonstrate skeletal alterations consistent with $\mathrm{PH}$, whilst 10 individuals from Morotai and three from the Uattamdi (Kayoa) cranial remains were so affected.

\section{Skeletal indicators of stress and their relationship with stature and age-at-death}

The relationships between skeletal lesions, stature, and age-at-death can be basically assessed, but these results utilise only small samples and merely provide a potential starting point for inferring links between mortality and disease in the sample (Table 12.2). Mean estimated stature in the indeterminate group $(\mathrm{n}=7)$ was $165.8 \mathrm{~cm}(\mathrm{SD}=9.3)$, whereas identified males $(\mathrm{n}=4)$ and the sole identified female $(\mathrm{n}=1)$ were estimated to have reached a mean of $161.8 \mathrm{~cm}(\mathrm{SD}=7.4)$ and stature of $161.4 \mathrm{~cm}$ respectively. Stature assessment of adults found no difference in mean stature to be higher in individuals with LEH than in those without (158.4, SD=7.8 compared with 158.5, $\mathrm{SD}=12.9$ respectively) (Table 12.3). On the other hand, the mean stature of individuals with $\mathrm{PH}$ was higher than that of unaffected individuals $(165.2 \mathrm{~cm}, \mathrm{SD}=7.6$ compared with $158.4 \mathrm{~cm}$, $\mathrm{SD}=7.8$ respectively). However, the high standard deviations suggest cautious interpretation of the data. 
Table 12.2 Stature and skeletal markers of systemic stress.

\begin{tabular}{|c|c|c|c|c|c|}
\hline \multirow{2}{*}{$\begin{array}{l}\text { Individual } \\
\text { Tanjung Pinang } 1\end{array}$} & \multirow{2}{*}{$\begin{array}{l}\text { Stature (cm) } \\
\text { Indeterminate^ }^{\wedge}\end{array}$} & \multirow[t]{2}{*}{ SE $(\mathrm{cm})^{\mathrm{a}}$} & \multicolumn{2}{|c|}{ Porotic Hyperostosis } & \multirow{2}{*}{\begin{tabular}{|l} 
Linear Enamel \\
Hypoplasia
\end{tabular}} \\
\hline & & & Early stage & $\begin{array}{l}\begin{array}{l}\text { Bilateral superior parietal and frontal } \\
\text { (cranium) }\end{array} \\
\end{array}$ & \\
\hline Tanjung Pinang 2 & $152.9 \dagger$ & \pm 3.82 & None present & & Mild \\
\hline Tanjung Pinang 3 & Indeterminate^ & & Early stage & Bilateral posterior parietals (cranium) & Mild \\
\hline Tanjung Pinang 4 & Indeterminate^ & & Second stage & $\begin{array}{l}\text { Bilateral posterior parietals and } \\
\text { occipital (cranium). Possibly also } \\
\text { microporosity of orbitals }\end{array}$ & Mild \\
\hline Tanjung Pinang 5 & Indeterminate ${ }^{\wedge}$ & & Third stage & Bilateral posterior parietals (cranium) & $\begin{array}{l}\text { Prominent, } \\
\text { multiple }\end{array}$ \\
\hline Tanjung Pinang 6 & Indeterminate ${ }^{\wedge}$ & & Early stage & Bilateral posterior parietals (cranium) & Mild \\
\hline Tanjung Pinang 9 & Indeterminate ${ }^{\wedge}$ & & Third stage & Parietals and frontal (cranium) & $\begin{array}{l}\text { Prominent, } \\
\text { multiple }\end{array}$ \\
\hline $\begin{array}{l}\text { Tanjung Pinang } \\
10\end{array}$ & Indeterminate^ & & Third stage & Parietals and frontal (cranium) & Indeterminate^ \\
\hline $\begin{array}{l}\text { Tanjung Pinang } \\
\text { Unknown } 1 \text { Adult }\end{array}$ & Indeterminate ${ }^{\wedge}$ & & Indeterminate ${ }^{\wedge}$ & & Indeterminate ${ }^{\wedge}$ \\
\hline $\begin{array}{l}\text { Tanjung Pinang } \\
\text { Unknown } 2 \text { child }\end{array}$ & Indeterminate ${ }^{\wedge}$ & & Third stage & $\begin{array}{l}\text { Occipital (cranium). Further cranium } \\
\text { not available }\end{array}$ & Indeterminate ${ }^{\wedge}$ \\
\hline $\begin{array}{l}\text { Tanjung Pinang } \\
\text { Unknown } 3 \\
\text { subadult } \\
\end{array}$ & 120.5 to $128.2 \dagger$ & $\begin{array}{l} \pm 3.82 \text { to } \\
\pm 3.48\end{array}$ & Indeterminate ${ }^{\wedge}$ & & Mild \\
\hline $\begin{array}{l}\text { Tanjung Pinang } \\
\text { Unknown } 4 \\
\text { subadult }\end{array}$ & $145.7 \ddagger$ & \pm 7.12 & Indeterminate $^{\wedge}$ & & Indeterminate $^{\wedge}$ \\
\hline $\begin{array}{l}\text { Tanjung Pinang } \\
\text { Unknown } 5 \text { Adult } \\
\end{array}$ & $174.6 \S$ & & Indeterminate ${ }^{\wedge}$ & & Indeterminate $^{\wedge}$ \\
\hline $\begin{array}{l}\text { Tanjung Tulang } \\
\text { Adult } 1\end{array}$ & $\begin{array}{l}158.6 \text { to } \\
161.0 \dagger \ddagger\end{array}$ & \begin{tabular}{|l|} 
\pm 6.98 to \\
\pm 4.25
\end{tabular} & Third stage & Bilateral parietal, and frontal (cranium) & Indeterminate ${ }^{\wedge}$ \\
\hline $\begin{array}{l}\text { Tanjung Tulang } \\
\text { Juvenile }\end{array}$ & $132.2 \dagger$ & \pm 4.25 & Indeterminate ${ }^{\wedge}$ & & Absent \\
\hline $\begin{array}{l}\text { Tanjung Tulang } \\
\text { Adult } 2\end{array}$ & Indeterminate ${ }^{\wedge}$ & & Indeterminate ${ }^{\wedge}$ & & Indeterminate $^{\wedge}$ \\
\hline $\begin{array}{l}\text { Tanjung Tulang } \\
\text { Adult } 3\end{array}$ & Indeterminate^ & & Indeterminate^ & & Indeterminate ${ }^{\wedge}$ \\
\hline Daeo 1 Adult & $170.5 \ddagger$ & \pm 6.42 & Third stage & $\begin{array}{l}\text { Parietal and occipital (cranium). } \\
\text { Remains highly fragmentary }\end{array}$ & Indeterminate ${ }^{\wedge}$ \\
\hline Daeo 1 Juvenile & Indeterminate^ & & Indeterminate ${ }^{\wedge}$ & & Indeterminate $^{\wedge}$ \\
\hline Daeo 2-1 juvenile & 132.6 to $132.8 \dagger$ & \pm 4.25 & None present & & Indeterminate ${ }^{\wedge}$ \\
\hline Daeo 2-2 & Indeterminate^ & & None present" & & Absent \\
\hline Daeo 2-3 & $167.6 \neq$ & \pm 6.54 & None present" & & Absent \\
\hline Daeo 2-4 & $159.3 \S$ & \pm 5.30 & None present" & & Indeterminate ${ }^{\wedge}$ \\
\hline Daeo 2-5 & $171.3 \S$ & \pm 5.57 & None present" & & Indeterminate $^{\wedge}$ \\
\hline Daeo 2-6 & $145 \S$ & \pm 5.30 & None present" & & Indeterminate ${ }^{\wedge}$ \\
\hline Uattamdi 1 & Indeterminate ${ }^{\wedge}$ & & Final stage & $\begin{array}{l}\text { Widespread and present internally } \\
\text { (cranium). }\end{array}$ & Indeterminate ${ }^{\wedge}$ \\
\hline Uattamdi 2 & Indeterminate^ & & Third stage & Right parietal & Indeterminate ${ }^{\wedge}$ \\
\hline Uattamdi 3 & Indeterminate^ & & Early stage & Bilateral parietal, and frontal (cranium) & Indeterminate^ \\
\hline Uattamdi 4 & $163.8 \ddagger$ & \pm 5.99 & None present & & Indeterminate $^{\wedge}$ \\
\hline Uattamdi 5 & Indeterminate^ & & None present & & Indeterminate ${ }^{\wedge}$ \\
\hline
\end{tabular}




\begin{tabular}{|c|c|c|c|c|}
\hline Individual & Stature $(\mathrm{cm})$ & SE $(\mathrm{cm})^{\mathrm{a}}$ & Porotic Hypero & $\begin{array}{l}\text { Linear Enamel } \\
\text { Hypoplasia }\end{array}$ \\
\hline Uattamdi 6 & 145.9 to $152.9 \dagger$ & $\begin{array}{l} \pm 3.51 \text { to } \\
\pm 3.27\end{array}$ & None present" & Absent \\
\hline Uattamdi 7 & 161.7 to $164.3 \dagger$ & $\begin{array}{l} \pm 3.51 \text { to } \\
\pm 3.27\end{array}$ & None present" & Indeterminate ${ }^{\wedge}$ \\
\hline Uattamdi 8 & Indeterminate^ & & None present* & Indeterminate $^{\wedge}$ \\
\hline Uattamdi 9 & $\begin{array}{l}158.0 \text { to } \\
164.7 \dagger \neq \oint \\
\end{array}$ & $\begin{array}{l} \pm 5.28 \\
\pm 6.36 \\
\end{array}$ & None present" & Indeterminate^ \\
\hline Uattamdi 10 & 173.1 to $177.6 \delta$ & $\begin{array}{l} \pm 5.13 \text { to } \\
\pm 5.33\end{array}$ & None present" & Indeterminate^ \\
\hline $\begin{array}{l}\text { Golo individual } \\
\text { associated with } \\
\text { cranium }\end{array}$ & 162.2 to $165.7 \dagger$ & $\begin{array}{l} \pm 3.42 \text { to } \\
\pm 4.25\end{array}$ & None present & $\begin{array}{l}\text { Prominent, } \\
\text { multiple }\end{array}$ \\
\hline
\end{tabular}

^ Remains too fragmentary for reliable estimates

† Steele and McKern 1969

$\ddagger$ Byers, Akoshima and Curran 1989

$\S$ Meadows and Jantz 1992, modified

" Co-mingled fragmentary remains preventing identification of skeletal material to individual

a Where a range of possible statures is presented, the SE associated with the lowest and highest estimates is presented.

Source: Bronwyn Wyatt and Justyna Miszkiewicz.

Table 12.3 Adult individuals with both stature estimates and pathology assessments.

\begin{tabular}{|l|r|r|r|r|}
\hline & \multicolumn{1}{|c|}{ With LEH } & \multicolumn{1}{|c|}{ Without LEH } & \multicolumn{1}{|c|}{ With PH } & \multicolumn{1}{|c|}{ Without PH } \\
\hline Number $(\mathrm{n})$ & 2 & 2 & 2 & 2 \\
\hline Mean stature $(\mathrm{cm})$ & 158.4 & 158.5 & 165.2 & 158.4 \\
\hline
\end{tabular}

Source: Bronwyn Wyatt and Justyna Miszkiewicz.

The distributions of age-at-death categories with respect to stress indicators can provide further insight into skeletal health and disease in a few of the individuals (Table 12.4). The highest proportion of LEH-affected individuals were adolescents, with five of the seven individuals with dental remains affected. In young adults with dental remains, three of the five individuals demonstrated LEH, whilst the only elderly individual was also affected. No middle-aged adults with dental remains demonstrated changes to enamel consistent with LEH. With $\mathrm{PH}$, each age category, except for infants and elderly adults, had individuals demonstrating its presence-in all three middle-aged adults, five of the seven adolescents, and four of the five young adults.

Table 12.4 Pathology presence by age-at-death.

\begin{tabular}{|l|r|r|r|r|r|r|}
\hline & Infant & Child & Adolescent & Young adult & Middle aged adult & Elderly \\
\hline LEH & - & - & 5 & 3 & - & 1 \\
\hline With & - & - & 2 & 2 & - & - \\
\hline Without & 0 & 1 & 5 & 4 & 3 & - \\
\hline PH & - & - & 2 & 1 & - & 0 \\
\hline With & - & -7 &
\end{tabular}

Source: Bronwyn Wyatt and Justyna Miszkiewicz. 


\section{Discussion}

Assessment of adult stature suggests that the common experience of childhood physiological disruption did not greatly affect the overall growth of adult individuals. There was no substantial difference in individuals with LEH and those without, and a counter-intuitive difference between those with $\mathrm{PH}$ and those without. These findings, at least for LEH and its relationship with growth and stature, are in line with other ancient and contemporary populations (Temple 2008; Floyd and Littleton 2006). Indeed, stunted stature may be more a marker of continued exposure to stress and resource deprivation than a result of childhood disruption (Vercellotti et al. 2014). The results of this study, however, cannot provide sufficient evidence to support such a relationship due to the small sample size. Any substantial differences in LEH and $\mathrm{PH}$ between different age groups in the sample were not supported. The small sample sizes for older adults and young children restrict any attempt to detect differences in mortality based on childhood stress exposure. The majority of the material represented adolescents and young adults, but the degree to which this reflects true population mortality compared to burial sampling bias is unclear.

The presence of $\mathrm{PH}$ across the sample may reflect resource deficiencies in the population (Halcrow et al. 2014; Ortner 2003; Oxenham and Cavill 2010; Walker et al. 2009; Zuckerman et al. 2014). However, determination of specific micro-nutrient deficiencies is difficult given the incomplete skeletal material. In transitory populations, malnutrition may have been commonplace as new islands were colonised (Buckley et al. 2014). Acquired nutritional deficiencies are not the only potential cause of $\mathrm{PH}$, especially within tropical environments. Porotic hyperostosis has been long linked to acquired conditions such as anemia caused by parasitic infections, or genetically determined diseases that include thalassemia and sickle cell anaemia (Rivera and Mirazón Lahr 2017). Malaria has been associated with development of porotic lesions of the cranium and orbits (Rabino Massa et al. 2000). The skeletal changes observed in individuals suffering malaria are believed to result from haemolytic anaemia induced by parasites (Nyakeriga et al. 2004). Indeed, Gowland and Western (2012) have utilised spatial epidemiology to demonstrate that the presence and severity of $\mathrm{PH}$ (as well as cribra orbitalia) tend to match the distribution of endemic malaria, which is endemic today in North Maluku (Beebe and Cooper 2000; Clark and Kelly 1993; Sternberg 1884).

Genetic studies of contemporary populations within the islands suggest a high proportion of alleles conferring protection against malarial infection, resulting in ovalocytosis and alphathalassemia (Hill et al. 1985). Unique forms of alpha-thalassemia have been observed with a likely Melanesian origin (Tsukahara et al. 2006). Given this, minor forms of thalassemia may be partly responsible for the high prevalence of $\mathrm{PH}$ within the sample. High infant and maternal mortality also reflects increased malarial presence (Soren 2003), although this sample does not have this mortality pattern. However, it is acknowledged that the $\mathrm{PH}$ evaluation here was solely based on macroscopic observations of few samples, with no diagnostic support using radiography of the cranial bones (e.g. to assess the extent of trabecular thickening due to potential marrow hyperplasia). A more robust differential diagnosis based on the porous lesions in the crania would be possible only with more data.

Finally, the disproportionate number of males in the Morotai sites, together with the high incidence of LEH on this island, may reflect purposeful secondary cranial burial of primarily adolescent and young adult male skulls. However, it is uncertain whether the distribution of skeletal markers of stress, age-at-death, and sex-based risk of mortality in the burial sample can be truly reflective of the broader population.

\section{terra australis 50}




\section{Conclusions}

A basic palaeopathological assessment of this ancient Indonesian population has demonstrated the complexities of relating systemic stress exposure to longer-term health outcomes such as growth restriction or increased mortality. No clear relationship between childhood stress exposure, as indicated through LEH, and adult stature could be observed. The proportion of individuals with LEH was highest in the adolescent age group, with a decreased proportion in older age groups. This may suggest that those young individuals who would have experienced poor health, as inferred from their LEH record, may have been less likely to survive into adulthood. This is only a generalised suggestion, as assessing the direct and complex relationship between LEH and mortality requires a larger sample size. Porotic hyperostosis did not demonstrate any positive or negative relationship with stature or mortality risk, thus suggesting that the systemic causes of this condition were not uniform in their health impacts over time. 
This text is taken from The Spice Islands in Prehistory: Archaeology in the Northern Moluccas, Indonesia, edited by Peter Bellwood, published 2019 by ANU Press, The Australian National University, Canberra, Australia. 